\title{
Ruthenium Oxide Hexacyanoferrate as an Effective Electrode Modifier for Amperometric Detection of Iodate and Hydrogen Peroxide
}

\author{
Totka Dodevska, ${ }^{\star}$ Ivan Shterev, Yanna Lazarova and Dobrin Hadzhiev \\ Department of Organic Chemistry and Inorganic Chemistry, University of Food Technologies, \\ 26, Maritsa Boulevard, Plovdiv 4002, Bulgaria \\ *Corresponding author: E-mail: dodevska@mail.bg \\ Tel.: +359 32603 679; Fax: +35932644102
}

Received: 07-10-2020

\begin{abstract}
Ruthenium oxide hexacyanoferrate (RuOHCF) film was electrochemically deposited onto a glassy carbon (GC) surface using consecutive cyclic voltammetry as a facile and green synthetic strategy. The electrochemical behaviour and electrocatalytic properties of the modified electrode RuOHCF/GC were evaluated with regards to electroreduction of hydrogen peroxide and iodate in a strong acidic medium (pHs 1.0-2.0) by using different electrochemical techniques, including cyclic voltammetry and amperometry at a constant potential. Electrochemical studies indicated that RuOHCF/GC possess a high catalytic activity in both studied reactions, fast response and good reproducibility of the current signal. The $\mathrm{RuOHCF} / \mathrm{GC}$ exhibits enhanced electrocatalytic behaviour compared with other modified electrodes reported before. The simple and reproducible procedure for electrode fabrication, the wide linear range, anti-interference performance and long-time stability of the RuOHCF/GC make it a promising sensing material for practical quantitative determination of hydrogen peroxide and iodate. Remarkably, the reported modified electrode provided superior sensitive (1050 $\mu \mathrm{A}$ $\mathrm{mM}^{-1} \mathrm{~cm}^{-2}$ ) and highly selective amperometric detection of iodate.
\end{abstract}

Keywords: Ruthenium oxide hexacyanoferrate; sensor; iodate; hydrogen peroxide

\section{Introduction}

Recently, as an important class of inorganic poly-nuclear compounds Prussian blue (ferric hexacyanoferrate, $\mathrm{PB})$ and its analogues transition metal hexacyanoferrates (MHCF) have received considerable attention in material science and solid-state electrochemistry due to their unique characteristics - easy and cheap synthesis, ability to mediate/catalyze electrochemical reactions and faster kinetics. ${ }^{1}$ MHCF have been investigated for various applications, including electrochemical sensors/biosensors, solid-state batteries, catalysts and charge storage. ${ }^{2}$

MHCF are known as useful electrocatalysts in selected processes - electrode materials modified with MHCF enhance slow electron transfer reactions of target analytes, thus being useful as electrochemical sensors. These well-organized inorganic polymers are intensively suited for electrochemical application due to their simple preparative procedure, good stability and the ease by which interfacial properties can be controlled. ${ }^{3}$ Therefore, synthesis and deposition of MHCF and their use as electrode modifiers are of great interest.

Various metals have been used to prepare $\mathrm{MH}$ CF-modified electrodes by chemical ${ }^{4}$ or electrochemi$\mathrm{cal}^{2,5-11}$ methods. Data show that most of the modified electrodes were prepared via electrochemical deposition techniques owing to its low cost, low time consuming and well-defined structure forming ability by controlling the time, cycle number and nature of the electrolyte. Direct electrodeposition process using cyclic voltammetry (CV) is an efficient, "green", facile approach to assemble MHCF films on electrode surface. The use of $\mathrm{CV}$ as a modification technique makes it possible to convert relatively inexpensive substrate electrodes into electrocatalytically active and highly specific reusable electrochemical sensors.

The MHCF electrocatalytic effects were confirmed for $\mathrm{H}_{2} \mathrm{O}_{2},{ }^{1,4,10} \mathrm{NO}^{11}$ and some easily oxidizable species as ascorbic acid, ${ }^{2,8}$ dopamine, ${ }^{2,6}$ glucose, ${ }^{9}$ sulfite. ${ }^{5,7}$ The preparation of hexacyanoferrate films with ruthenium also has been reported. Generally, the formed films on the elec- 
trode surface exhibit high electrocatalytic activity in the cathodic reduction of $\mathrm{H}_{2} \mathrm{O}_{2}{ }^{12}$ and anodic oxidation of ethyl alcohol, ${ }^{13,14}$ isopropyl alcohol, ${ }^{13}$ L-cysteine, ${ }^{13}$ epinephrine, ${ }^{15}$ ranitidine, ${ }^{16}$ hydrazine,${ }^{17}$ deoxyguanosine, ${ }^{18}$ ascorbic acid, ${ }^{13,15}$ uric acid, ${ }^{15}$ sulfite. ${ }^{19}$ New type mixed-valent ruthenium oxide/hexacyanoruthenate film modified electrodes were applied successfully for electrocatalytic oxidation of $\mathrm{NADH}$, dopamine, $\mathrm{SO}_{3}{ }^{2-}, \mathrm{S}_{2} \mathrm{O}_{3}{ }^{2-}$ and hydrazine. ${ }^{20}$

To the best of our knowledge, no reports are available on the application of ruthenium oxide hexacyanoferrate as a catalyst in electroreduction of iodate. Potassium iodate has been used for iodination of commercial table salt. The use of iodized salt in household and in food manufacture is established as a safe and cost-effective measure to ensure sufficient iodine intake by all individuals. This is the most effective and sustainable strategy for mass prevention of iodine deficiency disorders (IDD) - a major worldwide public health problem affecting all groups of people of which pregnant women, lactating women and infants are the most vulnerable categories. ${ }^{21}$ Iodine is critical to brain and nervous system maturation during fetal/ early postnatal life. Iodine deficiency and hypothyroidism during pregnancy result in impaired somatic growth, neurocognition and low child intelligence quotient. On the other hand, an iodine-induced hyperthyroidism and thyrotoxicosis may result from acute or chronic excess iodine exposure, including the consumption of excessively iodized salt. Therefore, to ensure that the correct amounts of iodate are added in table salt, the sensitive and rapid quantitative determination is of great importance to preventing thyroid diseases. ${ }^{22,23}$ Several analytical techniques, such as spectrophotometry, ${ }^{24}$ flame atomic absorption spectrometry (FAAS), ${ }^{25}$ chemiluminescence ${ }^{26}$ and gas chromatography-mass spectrometry ${ }^{27}$ have been used for iodate sensing. However, most of these methods are not suitable for routine analysis as they required expensive equipment and some of them are based on indirect reactions where species with appropriate characteristics have to be produced for quantitative detection of the target analyte. Compared with these techniques, electrochemical sensors provide a simple, selective and inexpensive approach to monitor iodate content. Moreover, electrochemical sensing devices are portable, particularly well-suited for the sample-limited cases (capable of working in microliter to nanoliter volumes) without sacrificing sensitivity and can provide fast/ automated analysis.

In the field of electroanalytical chemistry a significant challenge is development of sensors for accurate and fast quantitative detection of hydrogen peroxide $\left(\mathrm{H}_{2} \mathrm{O}_{2}\right)$ an analyte of great interest in clinical, pharmaceutical, industrial and environmental analysis. Recently, there are a numerous studies on the development of effective electrocatalysts for reduction of $\mathrm{H}_{2} \mathrm{O}_{2}$ in neutral or weakly acidic medium because the low-potential detection of $\mathrm{H}_{2} \mathrm{O}_{2}$ is one of the most successful strategy for oxidase-based biosensors providing both sensitivity and extremely high se- lectivity in the presence of easily oxidizable compounds. ${ }^{28-34} \mathrm{H}_{2} \mathrm{O}_{2}$ is also an industrially relevant analyte - it is used in aseptic processing of food, beverages and pharmaceuticals; for industrial wastewater disinfection and decontamination; as an oxidizing and bleaching agent in the paper and textile industries. The acidic bleaching process is useful for textiles which are not stable in alkaline medium and is very selective for the coloured impurities, which means that even at high concentrations of bleaching agent, damage or degradation of the textile structure is not observed. ${ }^{35} \mathrm{H}_{2} \mathrm{O}_{2}$ is also believed to play a main role in the chemical degradation of polymer membranes in proton-exchange membrane fuel cells (PEMFCs), affecting the long-term performance and durability of PEMFCs. Under PEMFC operating conditions, $\mathrm{H}_{2} \mathrm{O}_{2}$ is produced to some extent and degrades the proton-exchange membrane, deteriorating the proton conductivity of the membrane. ${ }^{36}$ Hence, the direct $\mathrm{H}_{2} \mathrm{O}_{2}$ determination in an acidic medium is actually significant and appropriate. However, only a few studies have addressed hydrogen peroxide electroreduction in strongly acidic environment. ${ }^{10,37-43}$

In order to extend the application of MHCF in the field of the electrochemical sensors, we have electrochemically deposited RuOHCF onto glassy carbon (GC) and further used $\mathrm{RuOHCF} / \mathrm{GC}$ as a working electrode for reduction of iodate and hydrogen peroxide that has a potential in electrochemical sensor applications. This work demonstrates that the modified electrode RuOHCF/GC remains functional and provides stable and reproducible measurements of $\mathrm{H}_{2} \mathrm{O}_{2}$ and iodate in a strong acidic medium (pHs 1.0-2.0). The investigation of RuOHCF film stability and electrocatalytic effect on iodate reduction demonstrated that GC modified with RuOHFC works as an efficient catalyst with higher sensitivity and wider linear range compared to other sensors.

\section{Experimental}

\section{1. Materials, Apparatus and Measurements}

$\mathrm{RuCl}_{3} \times \mathrm{nH}_{2} \mathrm{O}, \mathrm{K}_{3}\left[\mathrm{Fe}(\mathrm{CN})_{6}\right], \mathrm{HCl}, \mathrm{KCl}, \mathrm{H}_{3} \mathrm{PO}_{4}$, $\mathrm{H}_{2} \mathrm{O}_{2}$ and $\mathrm{KIO}_{3}$ were purchased from Fluka; $\mathrm{Na}_{2} \mathrm{HPO}_{4} \times$ $12 \mathrm{H}_{2} \mathrm{O}$ and $\mathrm{NaH}_{2} \mathrm{PO}_{4} \times 2 \mathrm{H}_{2} \mathrm{O}$ were purchased from Sigma-Aldrich. All chemicals used were of analytical grade and double distilled water was used to prepare aqueous solutions. 0.1 M phosphate buffer solutions (PBS) with $\mathrm{pH}$ values 1.0, 2.0 and 3.0 were made of monobasic and dibasic sodium phosphates using a $\mathrm{pH}$ meter MS2006 (Microsyst, Bulgaria).

The electrochemical measurements were performed on electrochemical workstation EmStat2 (PalmSens BV, The Nederland), equipped with 'PSTrace 2.5.2' licensed software. Three-electrode system was employed to study the electrochemical performance of the modified electrode; $\mathrm{Pt}$ wire was used as a counter electrode and an $\mathrm{Ag} / \mathrm{AgCl}$ (3 M $\mathrm{KCl})$ as a reference electrode. The modified electrode was 
investigated using cyclic voltammetry and amperometry at a constant potential. Cyclic voltammograms were recorded at scan rates from 50 to $500 \mathrm{mV} \mathrm{s}^{-1}$; peak intensities of CVs were reported with baseline correction. Amperometric $(I-t)$ curves were monitored at a constant applied potential under hydrodynamic condition - magnetic stirrer was used to achieve effective mass transport across the working electrode. To remove oxygen, the background solution was purged with pure argon for about $20 \mathrm{~min}$ before performing electrochemical experiments and a continuous flow of argon was maintained during measurements.

\section{2. Electrochemical Deposition of RuOHCF on a Glassy Carbon Electrode}

Glassy carbon (GC) electrode ( $\mathrm{d}=3 \mathrm{~mm}$ ) was mechanically polished with $0.05 \mu \mathrm{m}$ alumina slurry, cleaned by ultrasonication in double distilled water for $5 \mathrm{~min}$ and allowed to dry at a room temperature. The preparation of the modified electrode RuOHCF/GC was done by electrochemical deposition of ruthenium hexacyanoferrate (RuOHCF) film on the glassy carbon surface by cyclic voltammetry from -0.5 to $1.3 \mathrm{~V}$ (vs. $\mathrm{Ag} / \mathrm{AgCl}, 3 \mathrm{M} \mathrm{KCl}$ ) in aqueous solution containing $0.05 \mathrm{M} \mathrm{HCl}+0.5 \mathrm{M} \mathrm{KCl}+$ $1 \% \mathrm{RuCl}_{3}+5 \mathrm{mM} \mathrm{K}_{3}\left[\mathrm{Fe}(\mathrm{CN})_{6}\right]$ applying 50 cycles at a scan rate of $100 \mathrm{mV} \mathrm{s}^{-1}$. The modified electrode RuOHCF/ GC was stored dry at a room temperature and no pre-treatment procedures were performed prior to the measurements.

\section{Results and Discussion}

\section{1. Electrochemical Behaviour of RuOHCF/ GC Modified Electrode}

CV is a powerful technique widely applied both in the preparation and characterization of various nano- and microstructured materials. ${ }^{44-46}$ The electrochemical behaviour of the modified electrode RuOHCF/GC was evaluated in strongly acidic aqueous solution by recording cyclic voltammograms in electrolyte $0.05 \mathrm{M} \mathrm{HCl}+0.5 \mathrm{M}$ $\mathrm{KCl}$ (pH 1.7). Fig. 1A presents CVs of the bare GC and $\mathrm{RuOHCF} / \mathrm{GC}$ registered in the potential range from -0.5 $\mathrm{V}$ to $1.3 \mathrm{~V}$. Compared with the bare GC electrode (red curve), the background voltammetric response of the modified electrode (black curve) is much higher indicating that the effective surface area is significantly enhanced. The voltammogram proves that the redox activity of $\mathrm{RuOHCF}$ film is based on the electron transfer processes involving $\mathrm{Ru}(\mathrm{II}) / \mathrm{Ru}(\mathrm{III}) / \mathrm{Ru}(\mathrm{IV})$ and $\mathrm{Fe}(\mathrm{II}) / \mathrm{Fe}$ (III) species and oxygen uptake. Four well-defined pairs of symmetrical anodic and cathodic peaks are registered. The redox couples I, III and IV with formal potentials $E_{\mathrm{p}}^{0}=\left(E_{\mathrm{p}}^{\mathrm{a}}+\right.$ $\left.E_{\mathrm{p}}^{\mathrm{c}}\right) / 2$ occurring at about $0.008,0.85$ and $1.03 \mathrm{~V}$ are attrib-
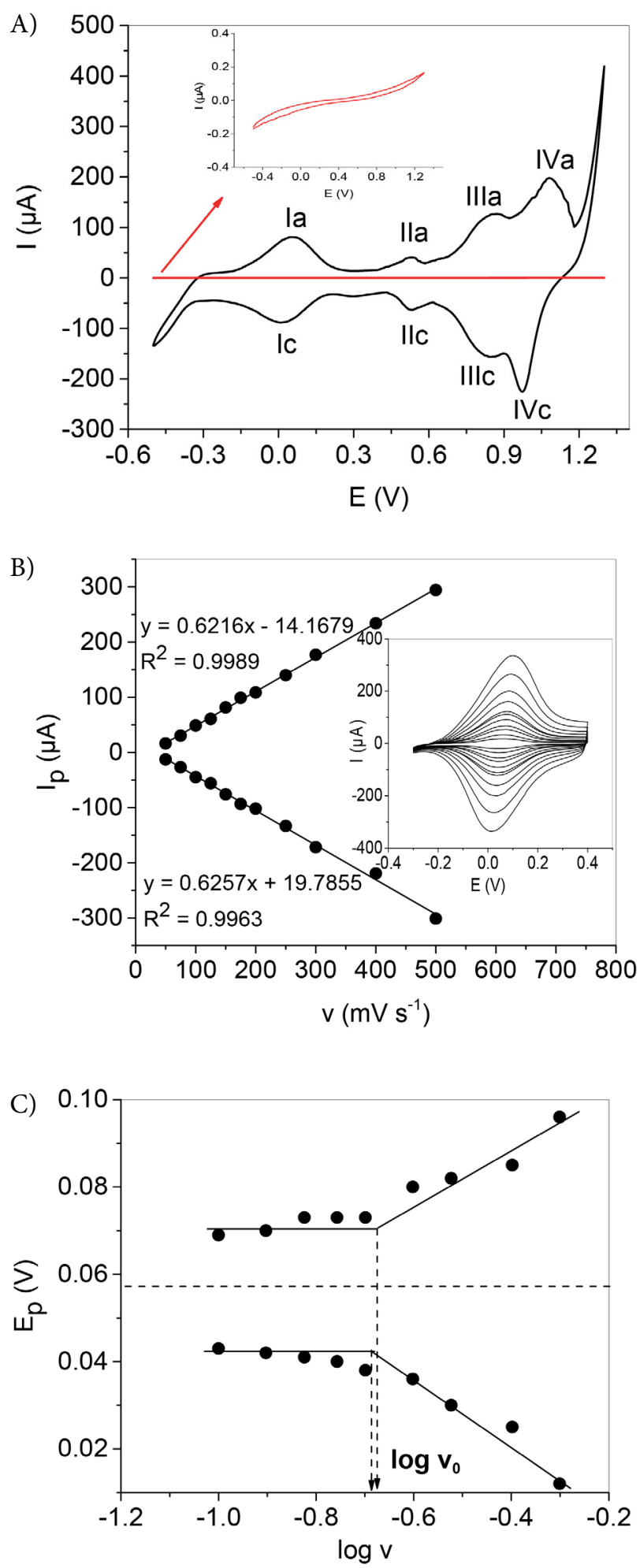

Fig. 1. A) CVs of unmodified GC electrode (red curve) and modified electrode RuOHCF/GC (black curve) recorded in electrolyte $0.05 \mathrm{M} \mathrm{HCl}+0.5 \mathrm{M} \mathrm{KCl}(\mathrm{pH} 1.7)$ at a scan rate of $100 \mathrm{mV} \mathrm{s}^{-1}$; Inset: enlarged plot showing the $\mathrm{CV}$ of bare GC. B) Plot of anodic and cathodic peak currents $v s$. scan rate for the first redox couple; Inset: $\mathrm{CVs}$ of $\mathrm{RuOHCF} / \mathrm{GC}$ at different scan rates (from inner to outer: 50, $\left.75,100,125,150,175,200,250,300,400,500 \mathrm{mV} \mathrm{s}^{-1}\right)$. C) Dependence of $E_{\mathrm{p}}$ on $\log (v)$. 
utable to the $[\mathrm{Ru}(\mathrm{II})-\mathrm{O} / \mathrm{Fe}(\mathrm{II})-\mathrm{CN}] /[\mathrm{Ru}(\mathrm{III})-\mathrm{O} / \mathrm{Fe}(\mathrm{II})-$ $\mathrm{CN}],[\mathrm{Ru}(\mathrm{III})-\mathrm{O} / \mathrm{Fe}(\mathrm{II})-\mathrm{CN}] /[\mathrm{Ru}(\mathrm{III})-\mathrm{O} / \mathrm{Fe}(\mathrm{III})-\mathrm{CN}]$ and $[\mathrm{Ru}(\mathrm{III})-\mathrm{O} / \mathrm{Fe}(\mathrm{III})-\mathrm{CN}] /[\mathrm{Ru}(\mathrm{IV})-\mathrm{O} / \mathrm{Fe}(\mathrm{III})-\mathrm{CN}]$ reactions. The redox coupe II (with formal potential at about $0.54 \mathrm{~V}$ ) exhibiting a small peak currents is due to the redox reaction of the electroactive iron sites [Ru(III)-NC-Fe(II)]/ $[\mathrm{Ru}(\mathrm{III})-\mathrm{NC}-\mathrm{Fe}(\mathrm{III})]$. This result confirms formation of mixed RuOHCF and RuHCF film on the GC electrode surface. ${ }^{13}$ It can be concluded that the used electrolyte, as well as the methodology for electrode modification described here, are reliable.

Chen et al. ${ }^{13}$ studied the $\mathrm{pH}$ effect of the supporting electrolyte on the voltammetric profile of RuOHCF films and demonstrated that the formal potentials of all four redox couples showed a positive shift due to the increase of acidity in the $\mathrm{pH}$ range $0.5-3.0$. At higher $\mathrm{pHs}$ a film loss has been reported, ${ }^{47}$ hence all the electrochemical measurements in this work were performed in supporting electrolytes with $\mathrm{pH}$ values in the range 1.0-3.0.

Fig. 1B shows the different scan rates results of $\mathrm{RuOHCF} / \mathrm{GC}$ in the potential range between -0.3 and 0.4 $\mathrm{V}$ (redox couple I). As illustrated, the anodic and cathodic peak currents increased linearly according to the scan rate as expected for the thin layer electrochemistry process. The corresponding linear regression equations were: $I_{\mathrm{p}}^{\mathrm{a}}$ $(\mu \mathrm{A})=0.6216 v\left(\mathrm{mV} \mathrm{s}^{-1}\right)-14.1679\left(\mathrm{R}^{2}=0.9989\right)$ and $I_{\mathrm{p}}^{\mathrm{c}}$ $(\mu \mathrm{A})=0.6257 v\left(\mathrm{mV} \mathrm{s}^{-1}\right)+19.7855\left(\mathrm{R}^{2}=0.9963\right)$; the ratio of the anodic to the cathodic peak current $\left(I_{\mathrm{p}}^{\mathrm{a}} / I_{\mathrm{p}}^{\mathrm{c}}\right)$ was equal to unity. The peak-to-peak potential separation $\left(\Delta E_{\mathrm{p}}=E_{\mathrm{p}}^{\mathrm{a}}\right.$ $\left.-E_{\mathrm{p}}^{\mathfrak{c}}\right)$ is small and about $30 \mathrm{mV}$ for sweep rates below 200 $\mathrm{mV} \mathrm{s}^{-1}$, suggesting facile charge transfer kinetics over this range of sweep rate. The behaviour illustrated in Fig. 1B is consistent with a diffusionless, reversible electron transfer process at low scan rates.

The apparent electron transfer rate constant $k^{0}$ were calculated from Tafel diagrams, using the theoretical value 0.5 for the charge transfer coefficient $(\alpha)$. Fig. 1C illustrates the graphical calculation of the critical scan rate $v_{0}$. Mean values of $k^{0}=9.6 \pm 0.1 \mathrm{~s}^{-1}$ were evaluated from the experimental data applying the equation $k^{0}=2.303 \alpha n F v_{0} / \mathrm{RT}$.

\section{2. Electrocatalytic Reduction of $\mathrm{H}_{2} \mathrm{O}_{2}$ at $\mathrm{RuOHCF/GC}$}

In the following section it has been experimentally proven that in such extreme acidic conditions the here presented RuOHCF/GC effectively reduces $\mathrm{H}_{2} \mathrm{O}_{2}$ and the electrode response is linear in a wide linear range of $\mathrm{H}_{2} \mathrm{O}_{2}$ concentrations. Voltammograms recorded in supporting electrolyte $0.05 \mathrm{M} \mathrm{HCl}+0.5 \mathrm{M} \mathrm{KCl}$ before and after the addition of hydrogen peroxide are shown in Fig. 2A. A current signal due to the [ $\mathrm{Ru}(\mathrm{II})-\mathrm{O} / \mathrm{Fe}(\mathrm{II})-\mathrm{CN}] /$ $[\mathrm{Ru}(\mathrm{III})-\mathrm{O} / \mathrm{Fe}(\mathrm{II})-\mathrm{CN}]$ redox process is registered - significant increase in the cathodic current and a decrease in the anodic current were observed when $\mathrm{H}_{2} \mathrm{O}_{2}$ is added. The obtained result indicates that the $\mathrm{Ru}(\mathrm{II} / \mathrm{III})$ cou- ple is responsible for the electrocatalytic reduction of $\mathrm{H}_{2} \mathrm{O}_{2}$.

Electroreduction of $\mathrm{H}_{2} \mathrm{O}_{2}$ at the surface of the modified electrode was studied by means of hydrodynamic amperometry - one of the most widely employed electrochemical technique for sensors. The amperometric measurements were carried out in deaerated constantly stirred background electrolyte $0.05 \mathrm{M} \mathrm{HCl}+0.5 \mathrm{M} \mathrm{KCl}$. The electrode working potential was held at $0.0 \mathrm{~V}$, and was selected from the CV (Fig. 2A). Fig. 2B displays the authentic record of amperometric response of RuOHCF/GC when different concentrations of $\mathrm{H}_{2} \mathrm{O}_{2}$ were injected consecutively at regular intervals of time. It can be seen that a stable and well-defined amperometric response was observed. Upon addition of $\mathrm{H}_{2} \mathrm{O}_{2}$ the modified electrode shows increasing staircase current response corresponding to the electrochemical reduction of the analyte. $\mathrm{RuOHCF} / \mathrm{GC}$ responds rapidly to the changes in $\mathrm{H}_{2} \mathrm{O}_{2}$ concentration producing a
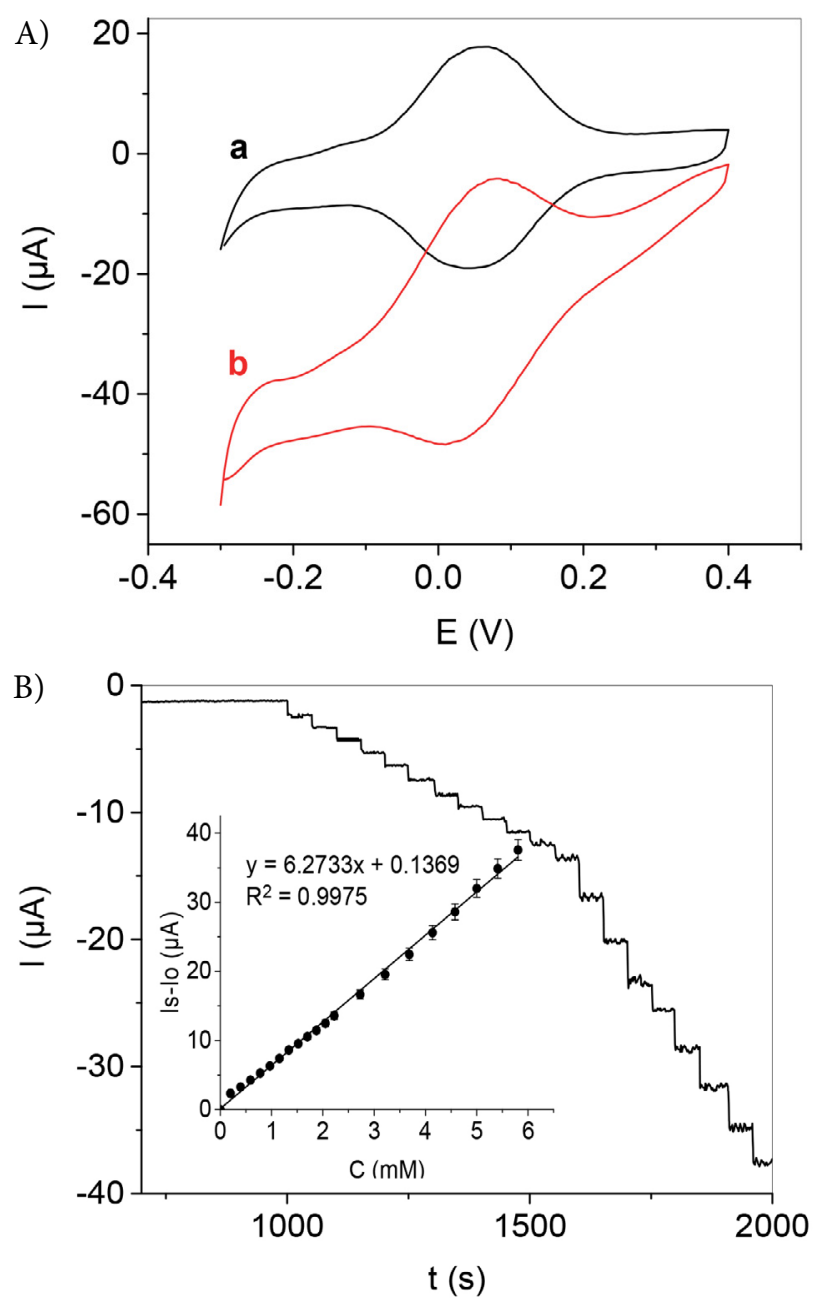

Fig. 2. A) CVs of RuOHCF/GC at scan rate of $50 \mathrm{mV} \mathrm{s}^{-1}$ in absence (curve a, black) and in presence of $3.0 \mathrm{mM} \mathrm{H}_{2} \mathrm{O}_{2}$ (curve b, red). B) Authentic record of the amperometric response for successive additions of $\mathrm{H}_{2} \mathrm{O}_{2}$ at an applied potential of $0.0 \mathrm{~V}$; Inset: the corresponding calibration plot. Supporting electrolyte $0.05 \mathrm{M} \mathrm{HCl}+0.5 \mathrm{M} \mathrm{KCl}$. 
Table 1. Comparison of the operational characteristics of amperometric sensors for $\mathrm{H}_{2} \mathrm{O}_{2}$ detection in strongly acidic medium with the achieved in the present work.

\begin{tabular}{|c|c|c|c|c|c|}
\hline Modifier/Electrode & $\begin{array}{l}\text { Method } \\
\text { E, (V) }\end{array}$ & Electrolyte & Sensitivity & $\begin{array}{l}\text { Linear range, } \\
(\mathrm{M})\end{array}$ & $\begin{array}{c}\text { Detection limit, } \\
\text { (M) }\end{array}$ \\
\hline $\mathrm{SnHCF} / \mathrm{CCE}^{10}$ & $\begin{array}{c}\text { CA } \\
-0.1^{b}\end{array}$ & $\begin{array}{c}\mathrm{ABS} / \mathrm{KNO}_{3} \\
(\mathrm{pH} 4.0)\end{array}$ & $0.588^{\mathrm{d}}$ & $4.0 \times 10^{-6}-5.0 \times 10^{-5}$ & $1.47 \times 10^{-6}$ \\
\hline $\mathrm{PMo}_{12}$-doped gel film/ $/ \mathrm{Pt}^{37}$ & $\begin{array}{l}\mathrm{CA} \\
0.0^{\mathrm{b}}\end{array}$ & $0.5 \mathrm{M} \mathrm{H}_{2} \mathrm{SO}_{4}$ & $3.6^{\mathrm{e}}$ & $2.0 \times 10^{-5}-3.0 \times 10^{-2}$ & $7.0 \times 10^{-6}$ \\
\hline PLL-GA-SiMo/GC 38 & $\begin{array}{c}\text { CA } \\
-0.05^{\mathrm{a}}\end{array}$ & $0.1 \mathrm{M} \mathrm{H}_{2} \mathrm{SO}_{4}$ & $0.6^{\mathrm{e}}$ & $5.0 \times 10^{-5}-5.0 \times 10^{-4}$ & - \\
\hline APS-PFeW $11 / \mathrm{CPE}^{39}$ & $\begin{array}{l}\text { FIA } \\
0.0^{\mathrm{a}}\end{array}$ & $0.5 \mathrm{M} \mathrm{H}_{2} \mathrm{SO}_{4}$ & $0.183^{\mathrm{c}}$ & $1.0 \times 10^{-5}-2.0 \times 10^{-4}$ & $7.4 \times 10^{-6}$ \\
\hline $\begin{array}{l}\text { Vanadium-17-molybdophosphate/ } \\
\text { graphite/methylsilicate composite }\end{array}$ & $\begin{array}{c}\text { CA } \\
0.205^{\mathrm{a}}\end{array}$ & $0.5 \mathrm{M} \mathrm{H}_{2} \mathrm{SO}_{4}$ & $324.0^{\mathrm{f}}$ & $1.0 \times 10^{-3}-7.5 \times 10^{-2}$ & $4.0 \times 10^{-4}$ \\
\hline PLL-GA-PW/GC ${ }^{41}$ & $\begin{array}{c}\text { CA } \\
-0.3^{\mathrm{a}}\end{array}$ & $0.1 \mathrm{M} \mathrm{H}_{2} \mathrm{SO}_{4}$ & $1.69^{\mathrm{e}}$ & $2.5 \times 10^{-6}-6.8 \times 10^{-3}$ & - \\
\hline $\mathrm{P}_{2} \mathrm{Mo}_{18} / \mathrm{OMC} / \mathrm{GC}^{42}$ & $\begin{array}{l}\text { CA } \\
0.0^{\mathrm{a}}\end{array}$ & $1.0 \mathrm{M} \mathrm{H}_{2} \mathrm{SO}_{4}$ & - & $1.6 \times 10^{-4}-4.4 \times 10^{-2}$ & $5.3 \times 10^{-5}$ \\
\hline $\mathrm{PB} / \mathrm{FTO}^{43}$ & $\begin{array}{c}\text { CA } \\
-0.1^{\mathrm{a}}\end{array}$ & $\begin{array}{l}\mathrm{HCl} / \mathrm{KCl} \\
(\mathrm{pH} 2.0)\end{array}$ & $0.05^{\mathrm{h}}$ & $9.0 \times 10^{-5}-3.5 \times 10^{-4}$ & $3.6 \times 10^{-5}$ \\
\hline $\mathrm{RuOHCF} / \mathrm{GC}^{\text {This work }}$ & $\begin{array}{l}\text { CA } \\
0.0^{\mathrm{a}}\end{array}$ & $\begin{array}{l}\mathrm{HCl} / \mathrm{KCl} \\
(\mathrm{pH} 1.7)\end{array}$ & $88.7^{\mathrm{g}}$ & $8.0 \times 10^{-5}-6.0 \times 10^{-3}$ & $5.0 \times 10^{-5}$ \\
\hline
\end{tabular}

${ }^{a}$ Reference electrode: Ag/AgCl, $3 \mathrm{M} \mathrm{KCl}\left(0.200 \mathrm{~V}\right.$ vs. SHE); ${ }^{\mathrm{b}}$ Reference electrode: saturated calomel electrode (SCE) $\left(0.242 \mathrm{~V} v\right.$ s. SHE); ${ }^{\mathrm{c}}$ in: $\mathrm{nA}$ $\mu \mathrm{M}^{-1}$; ${ }^{\mathrm{d}}$ in: $\mu \mathrm{A} \mu \mathrm{M}^{-1}$; ${ }^{\mathrm{e}}$ in: $\mu \mathrm{A} \mathrm{mM}^{-1}$; ${ }^{\mathrm{f}}$ in: $\mathrm{nA} \mathrm{mM^{-1 }}$; ${ }^{g}$ in: $\mu \mathrm{AmM}^{-1} \mathrm{~cm}^{-2}$; ${ }^{\mathrm{h}}$ in: $\mu \mathrm{A} \mu \mathrm{M}^{-1} \mathrm{~cm}^{-2}$; CCE - carbon ceramic electrode; CPE - carbon paste electrode; CA - chronoamperometry; FIA - flow injection analysis; $\mathrm{PMo}_{12}$ - 12-molybdophosphoric acid; PLL-GA-SiMo - silicomolybdate-doped-glutaraldehyde-crosslinked poly-l-lysine film; APS- $\mathrm{PFeW}_{11}-\left[\mathrm{PFeW}_{11} \mathrm{O}_{39}\right]^{4-}$ polyoxoanion supported on modified amorphous silica gel; PLL-GA-PW - phosphotungstate-doped-glutaraldehyde-cross-linked poly-l-lysine film; $\mathrm{P}_{2} \mathrm{Mo}_{18}$ - polyoxometalate $\mathrm{H}_{6} \mathrm{P}_{2} \mathrm{Mo}_{18} \mathrm{O}_{62} \cdot \mathrm{xH}_{2} \mathrm{O} ; \mathrm{OMC}$ - ordered mesoporous carbon; PB - Prussian blue; FTO - F-doped tin oxide; ABS - acetate buffer solution.

stable current signal in less than $8 \mathrm{~s}$. The observed features confirm the catalytic ability of RuOHCF film and indicate a fast electron-transfer process at the modified electrode surface. The background subtracted steady-state current response of $\mathrm{RuOHCF} / \mathrm{GC}$ was proportional to the $\mathrm{H}_{2} \mathrm{O}_{2}$ concentration up to $6.0 \mathrm{mM}$; the regression equation was $I$ $(\mu \mathrm{A})=6.2733 \mathrm{C}(\mathrm{mM})+0.1369$ with a correlation coefficient of 0.9975 , indicating that the regression line is very well fitted with the experimental data. Therefore, the calibration equation can be used for the determination of unknown samples. The electrode shows electrochemical sensitivity of $88.7 \mu \mathrm{A} \mathrm{mM}^{-1} \mathrm{~cm}^{-2}$ (normalization is based on the electrode geometric surface area) calculated on the basis of 20 points. The detection limit was estimated to be $0.05 \mathrm{mM} \mathrm{H}_{2} \mathrm{O}_{2}$ (based on signal-to-noise ratio $\mathrm{S} / \mathrm{N}=3$ ).

To assess the reproducibility of the measurements, the response (reduction current) for $1.0 \mathrm{mM} \mathrm{H}_{2} \mathrm{O}_{2}$ was recorded five times using the same electrode. The results confirmed that the electrode signal of RuOHCF/GC had good reproducibility with a relative standard deviation (RSD) less than $5.0 \%$.

A limited number of $\mathrm{H}_{2} \mathrm{O}_{2}$ sensors operating in strongly acidic medium have been reported in literature. To the best of our efforts, eight various $\mathrm{H}_{2} \mathrm{O}_{2}$ amperometric sensors are summarized in Table 1 with respect to the opetaring conditions (electrolyte and applied potential), sensitivity, linear range and detection limit. ${ }^{10,37-43}$ It is ap- parent that the operational characteristics for $\mathrm{H}_{2} \mathrm{O}_{2}$ quantitative determination at $\mathrm{RuOHCF} / \mathrm{GC}$ are comparable and even better than those obtained by using other modified electrodes. Despite the detection limit of RuOHCF/ GC is not so low when compared to other electrodes, the proposed sensor exhibited a wider linear concentration range. Moreover, it should be pointed that lower values of detection limit and higher sensitivity could be achieved increasing the amount of electrodeposited material onto to the surface of glassy carbon electrode. We are convinced that these operational characteristics of the proposed electrode could be improved by optimizing the scan rate and the number of cycles applied for modification of the glassy carbon carrier. In this regard, the aim of our future research is to determine how the parameters of electrodeposition process affect the catalytic activity of RuOHCF/GC in the target reaction $\left(\mathrm{H}_{2} \mathrm{O}_{2}\right.$ electroreduction).

\section{3. Electrocatalytic Reduction of Iodate at $\mathrm{RuOHCF/GC}$}

Voltammetric characteristics of the RuOHCF film are $\mathrm{pH}$-dependent. Therefore, all the electrochemical measurements were carry out in buffer solution ( $\mathrm{pH} 1.0)$ in order to maintain a constant $\mathrm{pH}$ of the supporting electrolyte. Under the same experimental conditions Salimi et al. ${ }^{48}$ have studied the activity of glassy carbon 


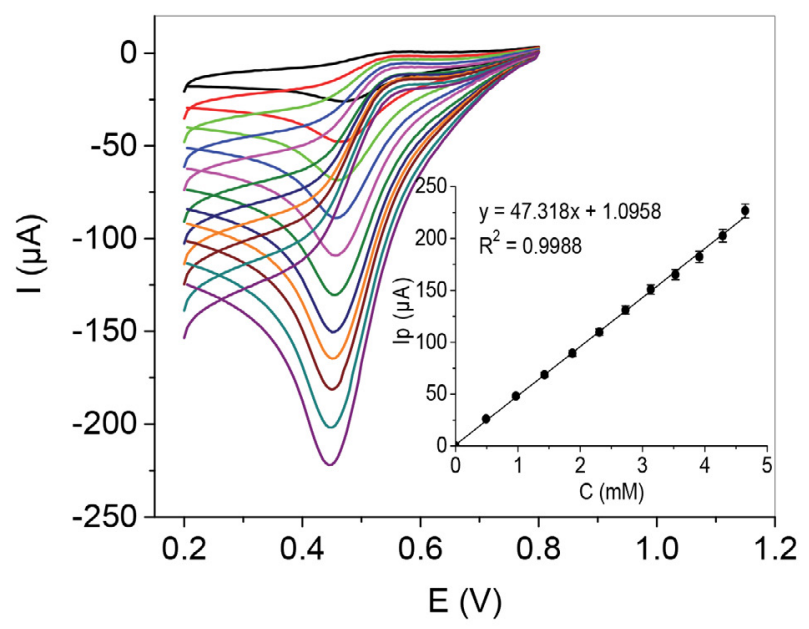

Fig. 3. Voltammetric response of $\mathrm{RuOHCF} / \mathrm{GC}$ in $\mathrm{PBS}$ (pH 1.0) containing different concentration of iodate; scan rate of $100 \mathrm{mV}$ $\mathrm{s}^{-1}$; Inset: plot of catalytic peak current $v s$. iodate concentration.

on the reduction of $\mathrm{IO}_{3}^{-}$and have shown that unmodified GC electrode responds sluggish to iodate at potentials more negative than $-0.5 \mathrm{~V}$ (vs. $\mathrm{Ag} / \mathrm{AgCl}$ ). In order to investigate the electrocatalytic activity of $\mathrm{RuOHCF} / \mathrm{GC}$ for reduction of iodate, $\mathrm{CV}$ responces of the modified electrode were obtained in PBS ( $\mathrm{pH} 1.0)$ in absence and presence of $\mathrm{IO}_{3}{ }^{-}$(Fig. 3). After addition of iodate into the supporting buffer solution the voltammetric behavior of RuOHCF/GC was changed dramatically - a remarkable cathodic peak at about $0.45 \mathrm{~V}$ was observed, indicating that the RuOHCF film can electrocatalyze reduction of iodate. The voltammetric responces of the modified electrode were recorded for different concentrations of $\mathrm{KIO}_{3}$. From the inset, it can be seen that with the increase of the iodate concentration, the corresponding catalytic currents enhanced linearly, suggesting that $\mathrm{RuOHCF} / \mathrm{GC}$ would have potential applications in the quantitative detection of $\mathrm{IO}_{3}{ }^{-}$. The sensitivity of the proposed electrode was calculated to be $669.3 \mu \mathrm{A} \mathrm{mM} \mathrm{mM}^{-1} \mathrm{~cm}^{-2}$ up to $4.8 \mathrm{mM}$ iodate.

Electroreduction of iodate at the surface of RuOHCF/ GC was studied also by means of hydrodynamic amperometry. For sensing purposes chronoamperometry under stirred conditions is preferred over $\mathrm{CV}$ technique because it provides a higher sensitivity, best selectivity and a lower detection limit. The amperometric response of $\mathrm{RuOHCF} /$ GC to iodate was investigated in deaerated constantly stirred buffer solution ( $\mathrm{pH} 1.0$ ). A potential of $0.45 \mathrm{~V}$ was kept as an applied potential considering the reduction peak from the CV record (Fig. 3). Fig. 4A shows typical current-time curve for successive additions of iodate. The current immediately changed after the addition of iodate and reached steady-state value within $5 \mathrm{~s}$ (Fig. 4A, inset a). Inset $\mathrm{b}$ of Fig. $4 \mathrm{~A}$ shows the fast response of the catalyst as well as the stability of the signal in presence of $0.1 \mathrm{mM}$ iodate during a prolonged $8 \mathrm{~min}$ experiment. The response remained stable throughout the experiment, indicating no
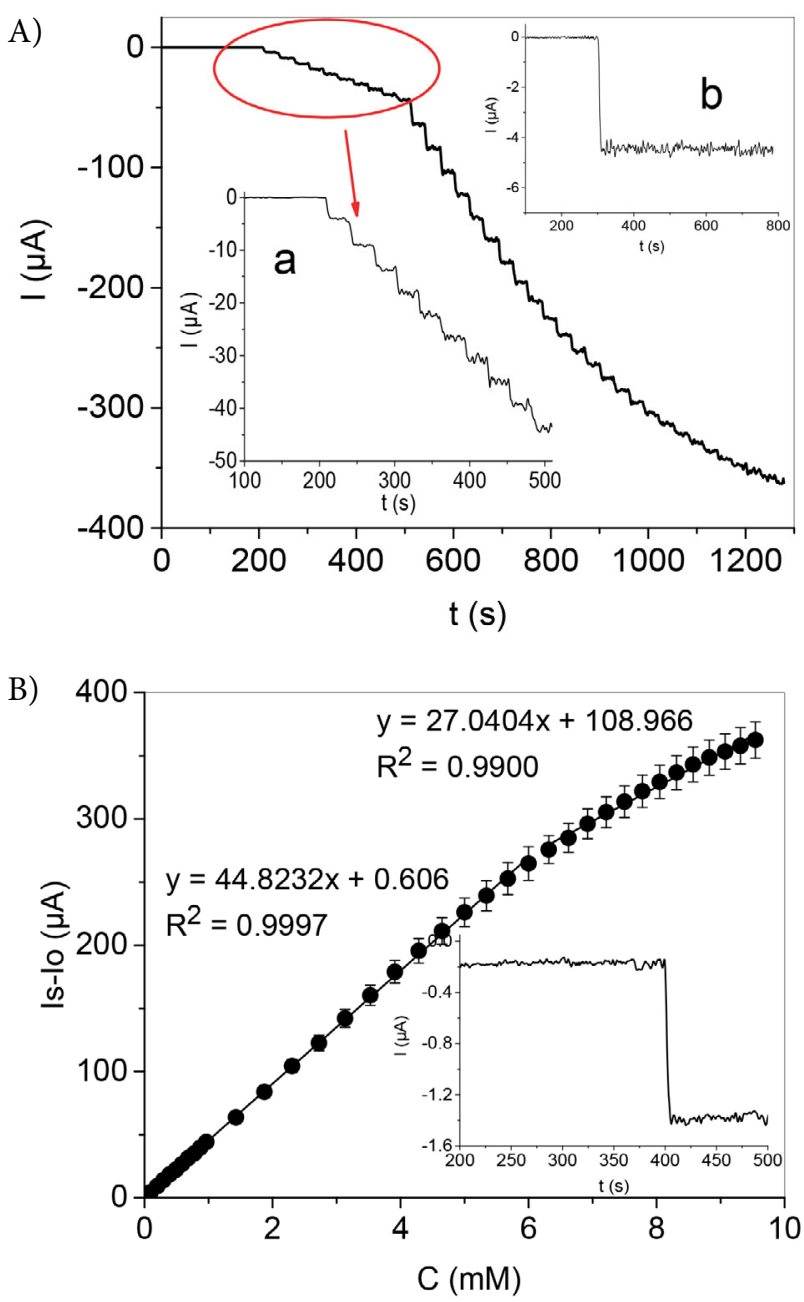

Fig. 4. A) Authentic record of the amperometric response of RuOHCF/GC in PBS ( $\mathrm{pH} 1.0$ ) for successive additions of iodate at potential of $0.45 \mathrm{~V}$; Insets: a) The enlarged initial section of the amperometric curve (10 injections of $0.1 \mathrm{mM} \mathrm{KIO}_{3}$ were added); $b$ ) Recorded amperogram of $0.1 \mathrm{mM}$ iodate (added in $300 \mathrm{~s}$ ) during long period time $8 \mathrm{~min}$. B) Calibration plot of chronoamperometric currents $v s$. iodate concentration in two concentration ranges: from 0.1 to $6.0 \mathrm{mM}$ (23 points) and from 6.0 to $9.5 \mathrm{mM}$ (14 points); Inset: Amperometric response for $20 \mu \mathrm{M}$ iodate.

inhibiting effect of $\mathrm{KIO}_{3}$ and/or its reduction products on the RuOHCF/GC surface.

Fig. 4B presents calibration plot of the background subtracted currents $v s$. iodate concentration in the range $0.1-9.5 \mathrm{mM}$. The plot shows two segmented linear calibration ranges - the first one is up to $6.0 \mathrm{mM}$ iodate with a linear regression equation $I(\mu \mathrm{A})=44.8232 C(\mathrm{mM})+$ 0.606 and a correlation coefficient of 0.9997 . The high active surface area has given superior performance - the electrode shows electrochemical sensitivity of $634.0 \mu \mathrm{A}$ $\mathrm{mM}^{-1} \mathrm{~cm}^{-2}$ calculated on the basis of 23 points. In the concentration range from 6.0 to $9.5 \mathrm{mM}$ iodate the linear regression equation is $I(\mu \mathrm{A})=27.0404 C(\mathrm{mM})+108.966$; the sensitivity and the correlation coefficient are $392.5 \mu \mathrm{A}$ $\mathrm{mM}^{-1} \mathrm{~cm}^{-2}$ and 0.990 , respectively. The detection limit 
was estimated to be $1.0 \mu \mathrm{M}$ (Fig. $4 \mathrm{~B}$, inset), based on the criterion of $\mathrm{S} / \mathrm{N}=3$.

In order to evaluate the reproducibility of the electrochemical performance of the modified electrode $\mathrm{RuOHCF} / \mathrm{GC}$, amperometric measurements at a constant potential of $0.45 \mathrm{~V}$ were repeatedly performed five times in a solution containing $0.1 \mathrm{mM} \mathrm{KIO}_{3}$. The proposed electrode showed a good repeatable and reproducible response for iodate. The current values for $0.1 \mathrm{mM}$ iodate were detected with RSD of $3.4 \%(n=5)$.

Additional experiments with glassy carbon electrodes modified with RuOHCF by applying 15 and $75 \mathrm{cy}-$ cles, respectively, were performed. Amperometric responses of the so-modified catalysts were registered in the presence of $0.1 \mathrm{mM} \mathrm{KIO}_{3}$ at an applied potential of $0.45 \mathrm{~V}$. It was established that the electrode modified by 15 cycles has a lower current response accompanied with a high noise and it is not applicable for analytical measurement of iodate. As expected, increasing the amount of electrodeposited RuOHCF onto the GC surface, the current signal has been improved - results obtained with the electrode modified with a thicker RuOHCF layer (75 cycles) were better in terms of higher signal and lower noise levels, i. e. lower limit of detection values could be achieved increasing the amount of electrodeposited material onto the GC electrode. Comparison of the catalytic current of electrode modified by 50 cycles with that of electrode modified by 75 cycles clearly indicates that the catalytic ability of both electrodes toward reduction of iodate is an identical. These results suggest that the electrodeposition procedure with 50 cycles of $\mathrm{CV}$ is favourable for a good catalytic activity, stable response and long durability. Therefore, all the electrochemical data presented below were obtained using an electrode modified with RuOHCF by applying 50 cycles.

In amperometric $I-t$ detection the potential applied to the working electrode directly affects the sensitivity, detection limit and selectivity of the electrochemical sensor. With regard to the latter, we have investigated the effect of the applied potential on the current response of $\mathrm{RuOHCF} /$ GC towards reduction of $\mathrm{IO}_{3}{ }^{-}$. A series of chronoamperometric measurements of different concentrations of $\mathrm{KIO}_{3}$ were done at potentials around $0.0 \mathrm{~V}$ (vs. $\mathrm{Ag} / \mathrm{AgCl}, 3 \mathrm{M}$ $\mathrm{KCl})$. At such a low potentials the current response of other electroactive species is eliminated (or minimized), which is crucial for the selectivity of the sensor system.

Fig. 5 displays the calibration graph based on the results obtained at a constant potential of $0.0 \mathrm{~V}$. It is apparent that the modified electrode shows staircase current response corresponding to the electrochemical reduction of the analyte, which evidences a stable and efficient catalytic property of RuOHCF film at low potentials (Fig. 5, inset a). Experimental data show that this decrease in the applied potential affects the process of iodate electroreduction on the modified electrode. Comparing the results obtained at potentials of $0.45 \mathrm{~V}$ and $0.0 \mathrm{~V}$, higher currents (Fig. 5, insets) and hence better electrode sensitivity were observed at the lower potential. However, the linear dynamic range is shortened significantly - the authentic record of the amperometric response at $0.0 \mathrm{~V}$ clearly shows that the signal noise increases rapidly with each subsequent injection of $\mathrm{IO}_{3}{ }^{-}$stock solution. The limit of detection was calculated to be $1.0 \mu \mathrm{M}$ iodate.

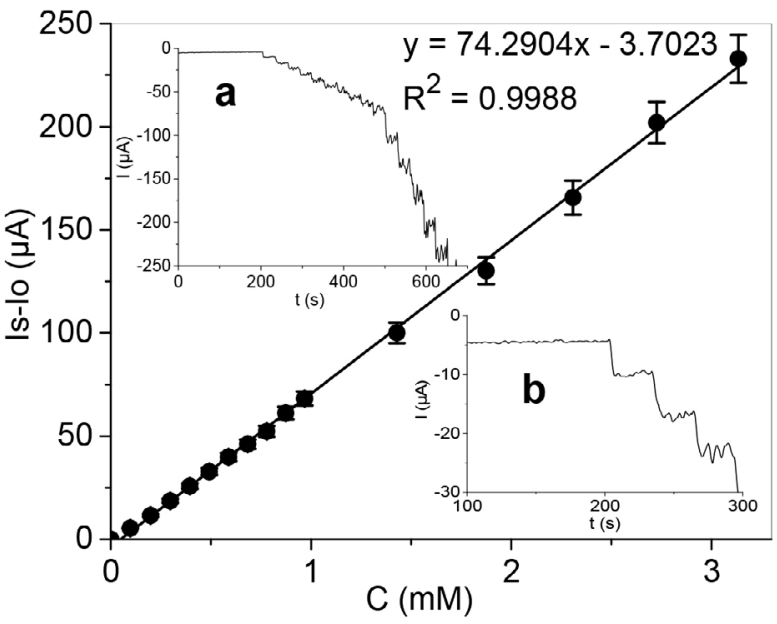

Fig. 5. Calibration plot of chronoamperometric currents $v s$. iodate concentration at an applied potential of $0.0 \mathrm{~V}$; Insets: a) Authentic record of the amperometric response of RuOHCF/GC in PBS ( $\mathrm{pH}$ 1.0) for successive additions of iodate; $b$ ) The enlarged initial section of the amperometric curve ( 3 injections of $0.1 \mathrm{mM} \mathrm{KIO}_{3}$ were added).

Table 2. Analytical parameters of RuOHCF/GC for iodate detection in PBS (pH 1.0); temperature $25^{\circ} \mathrm{C}$.

\begin{tabular}{|c|c|c|c|c|}
\hline $\mathrm{E},(\mathrm{V})$ & Regression equation & $\begin{array}{l}\text { Electrode sensitivity, } \\
\qquad\left(\mu \mathrm{A} \mathrm{mM}^{-1} \mathrm{~cm}^{-2}\right)\end{array}$ & $\begin{array}{l}\text { Linearity, } \\
\text { (M) }\end{array}$ & $\begin{array}{c}\text { Detection limit, } \\
(\mathrm{M})\end{array}$ \\
\hline-0.1 & $\begin{array}{c}y=73.0277 x-3.1551 \\
\left(R^{2}=0.9989\right)\end{array}$ & 1033.0 & $8.0 \times 10^{-6}-2.7 \times 10^{-3}$ & $5.0 \times 10^{-6}$ \\
\hline 0.0 & $\begin{array}{c}\mathrm{y}=74.2904 \mathrm{x}-3.7023 \\
\left(\mathrm{R}^{2}=0.9988\right)\end{array}$ & 1050.8 & $5.0 \times 10^{-6}-3.2 \times 10^{-3}$ & $1.0 \times 10^{-6}$ \\
\hline 0.1 & $\begin{aligned} y= & 69.4068 x-1.1804 \\
& \left(R^{2}=0.9997\right)\end{aligned}$ & 981.7 & $5.0 \times 10^{-6}-2.7 \times 10^{-3}$ & $1.0 \times 10^{-6}$ \\
\hline 0.45 & $\begin{aligned} y= & 44.8232 x+0.606 \\
& \left(R^{2}=0.9997\right)\end{aligned}$ & 634.0 & $8.0 \times 10^{-6}-6.0 \times 10^{-3}$ & $1.0 \times 10^{-6}$ \\
\hline
\end{tabular}




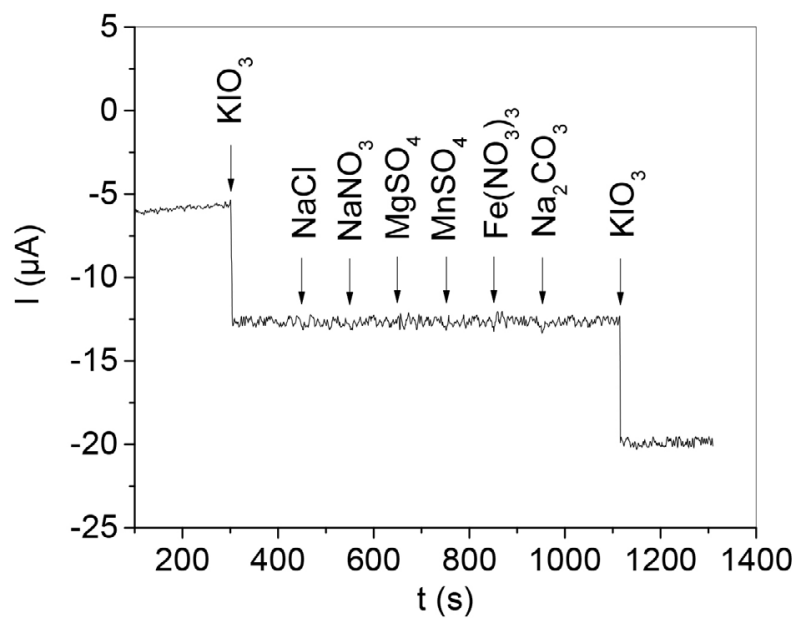

Fig. 6. Amperometric $I-t$ curve of modified electrode RuOHCF/GC for the determination of $0.1 \mathrm{mM} \mathrm{KIO}_{3}$ in the presence of $3.3 \mathrm{mM}$ of different interfering species added one by one with an interval of $100 \mathrm{~s}$ to $\mathrm{PBS}(\mathrm{pH} 1.0)$ at an applied potential of $-0.1 \mathrm{~V}$.

To estimate the sensing properties of modified electrode, the analytical parameters in terms of sensitivity, linear range and detection limit at four applied potentials were defined and compared (Table 2). From the data presented it is evident that as the polarization potential become more negative than $0.45 \mathrm{~V}$, the sensitivity increases. The comparison made shows that at potentials of $-0.1,0.0$ and $0.1 \mathrm{~V}$ the electrode sensitivity values are very close and the range of the strict linear concentration dependence of the current signal is almost unaffected by the applied potential.

In order to examine the $\mathrm{pH}$ effect on the catalytic reduction behaviour, the current response at an applied po- tential of $-0.1 \mathrm{~V}$ of RuOHCF/GC in $0.1 \mathrm{mM} \mathrm{KIO}_{3}$ at different $\mathrm{pH}$ values $(1.0,2.0$ and 3.0) was studied. It was found that the catalytic currents began to decrease with the increasing of the $\mathrm{pH}$. The modified electrode shows excellent electrocatalytic activity at $\mathrm{pH} 1.0 ; 20 \%$ decrease in current was observed at $\mathrm{pH} 2.0$; at $\mathrm{pH} 3.0$ the results were not repeatable. The observed features prove that the $\mathrm{pH}$ value has an effect on the electrode behaviour and this is related to the proton taking part in the electrochemical reaction.

To investigate the selectivity and anti-interference ability of RuOHCF/GC, a number of interfering species which possibly coexist with iodate in samples were added to the PBS (pH 1.0) containing $0.1 \mathrm{mM} \mathrm{KIO}_{3}$ at an applied potential of $-0.1 \mathrm{~V}$. As can be seen from Fig. 6, various ions such as $\mathrm{Na}^{+}, \mathrm{Fe}^{3+}, \mathrm{Mg}^{2+}, \mathrm{Mn}^{2+}, \mathrm{Cl}^{-}, \mathrm{SO}_{4}{ }^{2-}, \mathrm{NO}_{3}{ }^{-}$and $\mathrm{CO}_{3}{ }^{2-}$ (30-fold concentration relative to iodate) did not produce apparent current response, while a significant and stable signal was observed after addition of $\mathrm{KIO}_{3}$. Therefore, the $\mathrm{RuOHCF} / \mathrm{GC}$ can be used as a selective and highly sensitive sensor for iodate detection even in the presence of high concentrations of different electroactive ions.

The reproducibility and reliability of the fabrication procedure also were studied - four RuOHCF/GC electrodes were prepared independently under the same conditions and immediately after the surface modification were tested by amperometry at $-0.1 \mathrm{~V}$. The RSD of the modified electrodes responces toward $0.1 \mathrm{mM}$ iodate was $6.3 \%$, indicating good reproducibility between different $\mathrm{RuOHCF} / \mathrm{GC}$ electrodes and confirming that the fabrication method is reliable.

It is known that the long-term stability as well as the chemical stability in contact with the supporting electrolyte of the modified electrode are crucial in terms of prac-

Table 3. Analytical parameters reported for different modified electrodes towards iodate detection.

\begin{tabular}{|c|c|c|c|c|c|}
\hline Modifier/Electrode & $\mathrm{E},(\mathrm{V})$ & $\mathrm{pH}$ & Sensitivity & $\begin{array}{c}\text { Linear range, } \\
\text { (M) }\end{array}$ & $\begin{array}{c}\text { Detection limit, } \\
\text { (M) }\end{array}$ \\
\hline AgNPs/PGS/GC 49 & $-1.25^{\mathrm{b}}$ & 6.7 & $250^{\mathrm{i}}$ & $1.0 \times 10^{-4}-8.0 \times 10^{-4}$ & $5.0 \times 10^{-5}$ \\
\hline $\mathrm{OMC} / \mathrm{AgNPs} / \mathrm{GC}^{50}$ & $-0.65^{b}$ & 3.0 & $1.92^{\mathrm{h}}$ & $1.5 \times 10^{-5}-4.43 \times 10^{-3}$ & $3.01 \times 10^{-6}$ \\
\hline $\mathrm{FAD}-\mathrm{SiO}_{2} / \mathrm{ZrO}_{2} / \mathrm{C}^{51}$ & $-0.41^{\mathrm{b}}$ & 4.0 & - & $4.9 \times 10^{-5}-2.4 \times 10^{-3}$ & $1.46 \times 10^{-6}$ \\
\hline $\mathrm{WO}_{3} / \mathrm{PANI} / \mathrm{C}$ cloth $^{52}$ & $-0.25^{\mathrm{b}}$ & - & $0.541^{\mathrm{d}}$ & $1.0 \times 10^{-5}-5.0 \times 10^{-4}$ & $2.7 \times 10^{-6}$ \\
\hline $\mathrm{IrO}_{\mathrm{x}} / \mathrm{GC}^{23}$ & $-0.2^{\mathrm{a}}$ & 1.0 & $739.7^{\mathrm{g}}$ & $1.0 \times 10^{-6}-4.6 \times 10^{-3}$ & $5.0 \times 10^{-7}$ \\
\hline MWCNT@RB/GE 53 & $-0.1^{\mathrm{a}}$ & 2.0 & $0.77^{\mathrm{e}}$ & $2.5 \times 10^{-5}-7.5 \times 10^{-4}$ & $2.7 \times 10^{-6}$ \\
\hline MWCNTs/ $/\left[\mathrm{C}_{8} \mathrm{Py}\right]\left[\mathrm{PF}_{6}\right]-\mathrm{PMo}_{12} / \mathrm{GC}^{54}$ & $0.0^{\mathrm{a}}$ & 2.59 & $14.81^{\mathrm{e}}$ & $2.0 \times 10^{-5}-2.0 \times 10^{-3}$ & $1.5 \times 10^{-5}$ \\
\hline $\mathrm{RuOHCF} / \mathrm{GC}^{\text {This work }}$ & $0.0^{\mathrm{a}}$ & 1.0 & $1050.8^{g}$ & $5.0 \times 10^{-6}-3.2 \times 10^{-3}$ & $1.0 \times 10^{-6}$ \\
\hline RuONPs/GC 55 & $0.078^{\mathrm{b}}$ & 3.0 & $0.01^{\mathrm{d}}$ & $1.5 \times 10^{-6}-5.2 \times 10^{-4}$ & $9.0 \times 10^{-7}$ \\
\hline AuNPs/PEI/CNTs-COOH/ORC/Au ${ }^{56}$ & $0.15^{\mathrm{a}}$ & 2.0 & - & $1.0 \times 10^{-6}-2.0 \times 10^{-3}$ & $1.7 \times 10^{-7}$ \\
\hline V-Schiff base complex/MWCNT/GC 57 & $0.3^{\mathrm{a}}$ & 2.0 & $23.4^{\mathrm{c}}$ & $5.0 \times 10^{-7}-5.0 \times 10^{-4}$ & $3.5 \times 10^{-7}$ \\
\hline $\mathrm{RuOHCF} / \mathrm{GC}^{\text {This work }}$ & $0.45^{\mathrm{a}}$ & 1.0 & $\begin{array}{l}634.0^{\mathrm{g}} \\
392.5^{\mathrm{g}}\end{array}$ & $\begin{array}{l}8.0 \times 10^{-6}-6.0 \times 10^{-3} \\
6.0 \times 10^{-3}-9.5 \times 10^{-3}\end{array}$ & $1.0 \times 10^{-6}$ \\
\hline $\mathrm{IrO}_{\mathrm{x}} / \mathrm{GC}^{48}$ & $0.7^{\mathrm{a}}$ & 1.0 & $140.9^{c}$ & $1.0 \times 10^{-7}-3.5 \times 10^{-5}$ & $5.0 \times 10^{-9}$ \\
\hline
\end{tabular}

NPs - nanoparticles; PGS - pure graphite sheets; OMC - ordered mesoporous carbon; FAD - flavin adenine dinucleotide; PANI - polyaniline; MWCNT - multiwall carbon nanotubes; RB - riboflavin; $\left(\left[\mathrm{C}_{8} \mathrm{Py}\right]\left[\mathrm{PF}_{6}\right]\right)$ - n-octylpyridinum hexafluorophosphate; $\left(\mathrm{PMo}_{12}\right)$ - phosphomolybdic acid; PEI - polyethyleneimine; (CNTs-COOH) - carbon nanotubes functionalized with a carboxylic acid group; ORC - organoruthenium(II) complexes. ${ }^{\mathrm{i}}$ in: $\mathrm{A} \mathrm{M}^{-1} \mathrm{~m}^{-2}$. Other abbreviations are the same as Table 1. 
Table 4. Iodate content in iodized table salt samples determined by different methods.

\begin{tabular}{lccc}
\hline Table salt sample & $\begin{array}{c}\text { Proposed } \\
\text { amperometric method, } \\
\left(\mathbf{m g ~ k g}^{-\mathbf{1}}\right)\end{array}$ & $\begin{array}{c}\text { Reference } \\
\text { titration method, } \\
\left(\mathbf{m g ~ k g}^{-\mathbf{1}}\right)\end{array}$ & $\mathbf{R E}^{\star}, \mathbf{( \% )}$ \\
\hline Salt sample 1 & 32.5 & 33.6 & -3.3 \\
Salt sample 2 & 46.2 & 48.8 & -5.3 \\
\hline
\end{tabular}

${ }^{\star}$ Relative error $\mathrm{RE}=[100 \times($ electrochemical method - reference method $)] /$ reference method

tical applications. The storage stability of the here presented electrode was tested - the current response toward 0.1 $\mathrm{mM}$ iodate at an applied potential of $-0.1 \mathrm{~V}$ was measured every day. Results revealed the good stability of the electrodeposited RuOHCF film - the modified electrode retained about $90 \%$ of its initial catalytic activity after 10 days storage. Similar data on stability of electrodes modified with MHCF films have been reported by other authors. ${ }^{5,8,10}$

The performance of the as-prepared catalyst was compared with other sensors, as it shown in Table $3 .{ }^{23,48-57}$ The sensor systems were arranged in order of increasing the working potential. Clearly, the detection limit of some sensors is better than our results. However, the sensitivity and linear range for RuOHCF/GC are superior to many sensor systems, such as $\mathrm{AgNP} / \mathrm{PGS} / \mathrm{GC}^{49}, \mathrm{FAD}-\mathrm{SiO}_{2} / \mathrm{ZrO}_{2} / \mathrm{C}^{51}, \mathrm{WO}_{3} / \mathrm{PANI} /$ $\mathrm{C}^{52}, \quad$ MWCNT@RB/GE ${ }^{53}, \quad \mathrm{MWCNTs} /\left[\mathrm{C}_{8} \mathrm{Py}^{2}\left[\mathrm{PF}_{6}\right]-\mathrm{PMo}_{12} /\right.$ $\mathrm{GC}^{54}, \mathrm{RuONPs} / \mathrm{GC}^{55}$. Hence, it is conclusive that the reported $\mathrm{RuOHCF} / \mathrm{GC}$ exhibited substantial electrocatalytic behaviour toward the electrochemical sensing of iodate.

\section{4. Real Sample Analysis}

To evaluate the feasibility of the modified electrode $\mathrm{RuOHCF} / \mathrm{GC}$ for quantitative analysis of iodate in real samples, $\mathrm{RuOHCF} / \mathrm{GC}$ was applied to detect iodate content in two different samples of commercial iodized table salt. Following the previously described methodology ${ }^{23}$ amperometric measurements were carried out at a constant potential of $-0.1 \mathrm{~V}$ applying the standard addition method. The iodate content was also determined using classical procedure (titration with thiosulfate) to test the accuracy. The results obtained by RuOHCF-based electrochemical sensor and by titration were in good agreement and the relative error was below $6 \%$ indicating that the proposed amperometric method is reliable (Table 4).

All the results mentioned above suggest that the $\mathrm{RuOHCF} / \mathrm{GC}$ would represent promising material for future applications in amperometric sensor for fast and precise sensing of iodate in commercial salt.

\section{Conclusion}

In this work we have demonstrated the electrochemical behaviour of modified electrode RuOHCF/GC in a strong acidic medium (pHs 1.0-2.0) and its electrocatalytic activity towards the reduction of $\mathrm{H}_{2} \mathrm{O}_{2}$ and iodate. $\mathrm{RuOHCF} / \mathrm{GC}$ was used for sensitive detection of $\mathrm{H}_{2} \mathrm{O}_{2}$ and $\mathrm{IO}_{3}{ }^{-}$using hydrodynamic amperometry technique. The modified electrode showed wide concentration range and good reproducibility for $\mathrm{H}_{2} \mathrm{O}_{2}$ determination at an applied potential of $0.0 \mathrm{~V}$ (vs. $\mathrm{Ag} / \mathrm{AgCl}, 3 \mathrm{M} \mathrm{KCl}$ ), and provided a platform for the development of a robust electroanalytical system. The results presented in this work associated with the extremely high sensitivity, anti-interference ability, good accuracy and the response stability of $\mathrm{RuOHCF} / \mathrm{GC}$ in electroreduction of $\mathrm{IO}_{3}{ }^{-}$predict a favorable application of the sensor for iodate quantitative analysis.

\section{References}

1. A. Karyakin, Electroanalysis 2001, 13, 813-819. DOI:10.1002/1521-4109(200106)13:10<813::AID-ELAN 813> 3.0.CO;2-Z

2. Q. Wang, Q. Tang, Microchim. Acta 2015, 182, 671-677. DOI:10.1007/s00604-014-1371-X

3. R. Ojani, J.-B. Raoof, B. Norouzi, Electroanalysis 2008, 20, 1996-2002. DOI:10.1002/elan.200804278

4. H. Pang, Y. Zhang, T. Cheng, W.-Y. Lai, W. Huang, Nanoscale 2015, 7, 16012-16019. DOI:10.1039/C5NR04322K

5. K. Pandi, M. Sivakumar, S.-M. Chen, M. Sakthivel, G. Raghavi, T.-W. Chen, Y.-C. Liu, R. Madhu, J. Electrochem. Soc. 2018, 165, B469-B474. DOI:10.1149/2.1171810jes

6. T. Selvaraju, R. Ramaraj, J. Chem. Sci. 2014, 126, 11-16. DOI:10.1007/s12039-013-0547-y

7. B. Devadas, M. Sivakumar, S. M. Chen, S. Cheemalapati, Electrochim. Acta 2015, 176, 350-358.

DOI:10.1016/j.electacta.2015.07.022

8. T.-H. Tsai, T.-W. Chen, S.-M. Chen, Electroanalysis 2010, 22, 1655-1662. DOI:10.1002/elan.200900610

9. Z. Xue, N. He, H. Rao, C. Hu, X. Wang, H. Wang, X. Liu, X. Lu, Appl. Surf. Sci. 2017, 396, 515-522.

DOI:10.1016/j.apsusc.2016.10.185

10. H. Razmi, A. Taghvimi, Int. J. Electrochem. Sci. 2010, 5, 751760.

http://www.electrochemsci.org/papers/vol5/5060751.pdf

11. L. Berisha, A. Maloku, E. Andoni, T. Arbneshi, Am. J. Anal. Chem. 2014, 5, 308-315. DOI:10.4236/ajac.2014.55038

12. T. Paixão, M. Bertotti, Electroanalysis 2008, 20, 1671-1677. 


\section{DOI:10.1002/elan.200804231}

13. S.-M. Chen, M.-F. Lu, K.-C. Lin, J. Electroanal. Chem. 2005, 579, 163-174. DOI:10.1016/j.jelechem.2005.02.006

14. W. Costa, W. Cardoso, E. Marques, C. Bezerra, A. Ferreira, C. Song, J. Zhang, A. Marques, J. Braz. Chem. Soc. 2013, 24, 651-656. DOI:10.1016/j.tetasy.2013.04.014

15. J. B. Raoof, R. Ojani, M. Baghayeri, Anal. Methods 2011, 3, 2367-2373. DOI:10.1039/clay05305a

16. W. de Araújo, T. Paixão, Electroanalysis 2011, 23, 2549-2554. DOI:10.1002/elan.201100102

17. W. Costa, A. Marques, E. Marques, C. Bezerra, E. Sousa, W. Cardoso, C. Song, J. Zhang, J. Appl. Electrochem. 2010, 40, 375-382. DOI:10.1007/s10800-009-0006-0

18. T. Paixão, M. Bertotti, Electrochim. Acta 2007, 52, 2181-2188. DOI:10.1016/j.electacta.2006.08.035

19. R. Montes, E. Richter, R. Munoz. Electrochem. Commun. 2012, 21, 26-29. DOI:10.1016/j.elecom.2012.05.005

20. S.-M. Chen, S.-H. Hsueh, J. Electroanal. Chem. 2004, 566, 291-303. DOI:10.1016/j.jelechem.2003.11.040

21. G. Medeiros-Neto, I. Rubio, Endocrinology: Adult and Pediatric (Seventh Edition) 2016, 1584-1600.e3.

DOI:10.1016/B978-0-323-18907-1.00091-3

22. R. Katagiri, X. Yuan, S. Kobayashi, S. Sasaki, PLoS ONE 2017, 12(3), e0173722. DOI:10.1371/journal.pone.0173722

23. Y. Lazarova, I. Shterev, T. Dodevska, Monatsh. Chem. 2018, 149, 1955-1962. DOI:10.1007/s00706-018-2275-y

24. M. Araya, S. García, S. Pizarro, Anal. Methods 2020, 12, 205211. DOI:10.1039/C9AY02249J

25. Ö. Yalçinkaya, A. Türker, Acta Chim. Slov. 2010, 57, 491-497. http://acta-arhiv.chem-soc.si/57/57-2-491.pdf

26. O. Zui, A. Terletskaya, Fresenius J. Anal. Chem. 1995, 351, 212-215. DOI:10.1007/BF00321640

27. J. Dorman, S. Steinberg, Environ. Monit. Assess. 2010, 161, 229-236. DOI:10.1007/s10661-008-0740-5

28. V. Januzaj, V. Mula, G. Turdean, L. Muresan, Acta Chim. Slov. 2015, 62, 28-34. DOI:10.17344/acsi.2014.672

29. T. Dodevska, Y. Lazarova, I. Shterev, Acta Chim. Slov. 2019, 66, 762-776. DOI:10.17344/acsi.2019.5261

30. T. Dodevska, E. Horozova, N. Dimcheva, Anal. Bioanal. Chem. 2006, 386, 1413-1418.

DOI:10.1007/s00216-006-0682-0

31. E. Horozova, T. Dodevska, N. Dimcheva, J. Chem. Technol. Metall. 2008, 43, 59-64.

http://dl.uctm.edu/journal/node/j2008-1/8_Horozova_Dodevska-59-64.pdf

32. E. Horozova, T. Dodevska, N. Dimcheva, Bioelectrochemistry 2009, 74, 260-264. DOI:10.1016/j.bioelechem.2008.09.003

33. T. Dodevska, E. Horozova, N. Dimcheva, Cent. Eur. J. Chem. 2010, 8, 19-27. DOI:10.1016/j.bioelechem.2008.09.003

34. E. Horozova, T. Dodevska, N. Dimcheva, R. Mussarlieva, Int. J. Electrochem. 2011, Article ID 697698, 8 pages.

DOI:10.4061/2011/697698
35. C. Pastore, P. Kiekens, Surface Characteristics of Fibers and Textiles, Volume 94 of Surfactant Science, CRC Press, 2000, ISBN:1482289784, 9781482289787

36. T. Tsuneda, R. Singh, A. Iiyama, K. Miyatake, ACS Omega 2017, 2, 4053-4064. DOI:10.1021/acsomega.7b00594

37. W. Song, Y. Liu, N. Lu, H. Xu, C. Sun, Electrochim. Acta 2000, 45, 1639-1644. DOI:10.1016/S0013-4686(99)00326-6

38. Y.-C. Wu, R. Thangamuthu, S.-M. Chen, Electroanalysis 2009, 21, 210-214. DOI:10.1002/elan.200804423

39. H. Hamidi, E. Shams, B. Yadollahi, F. Esfahani, Electrochim. Acta 2009, 54, 3495-3500. DOI:10.1016/j.electacta.2008.12.063

40. P. Wang, X. Wang, G. Zhu, Chem. Lett. 2000, 29, 820-821. DOI: $10.1246 / \mathrm{cl} .2000 .820$

41. R. Thangamuthu, Y.-C. Pan, S.-M. Chen, Sens. Actuators B 2011, 151, 377-383. DOI:10.1016/j.snb.2010.08.028

42. M. Zhou, L. Guo, F. Lin, H. Liu, Anal. Chim. Acta 2007, 587, 124-131. DOI:10.1016/j.aca.2007.01.017

43. B. Pires, F. Galdino, J. Bonacin, Inorg. Chem. Acta 2017, 466, 166-173. DOI:10.1016/j.ica.2017.06.003

44. T. Dodevska, I. Shterev, Y. Lazarova, Acta Chim. Slov. 2018, 65, 970-979. DOI:10.17344/acsi.2018.4672

45. Y. Lazarova, T. Dodevska, Food Science and Applied Biotechnology 2018, 1, 63-69. DOI:10.30721/fsab2018.v1.i1.4

46. T. Dodevska, E. Horozova, N. Dimcheva, Mater. Sci. Eng. B 2013, 178, 1497-1502. DOI:10.1016/j.mseb.2013.08.012

47. L. Shaidarova, S. Ziganshina, L. Tikhonova, G. Budnikov, J. Anal. Chem. 2003, 58, 1144-1150.

DOI:10.1023/B:JANC.0000008953.67244.c2

48. A. Salimi, R. Hallaj, B. Kavosi, B. Hagighi, Anal. Chim. Acta 2010, 661, 28-34. DOI:10.1016/j.aca.2009.12.005

49. L. Guadagnini, D. Tonelli, Sens. Actuat. B 2013, 188, 806-814. DOI:10.1016/j.snb.2013.07.077

50. H. Heidari, B. Habibi, F. B. Vaigan, Anal. Methods 2016, 8 , 4406-4412. DOI:10.1039/C6AY01087C

51. E. Marafon, L. Kubota, Y. Gushikem, J. Solid State Electrochem. 2009, 13, 377-383. DOI:10.1007/s10008-008-0564-9

52. B.-X. Zou, X.-X. Liu, D. Diamond, K.-T. Lau, Electrochim. Acta 2010, 55, 3915-3920.

DOI:10.1016/j.electacta.2010.02.034

53. S. Nellaiappan, A. Kumar, Electrochim. Acta 2013, 109, 59-66. DOI:10.1016/j.electacta.2013.07.076

54. B. Haghighi, H. Hamidi, L. Gorton, Electrochim. Acta 2010, 55, 4750-4757. DOI:10.1016/j.electacta.2010.03.041

55. F. Chatraei, H. Zare, Mat. Sci. Eng. C 2013, 33, 721-726. DOI:10.1016/j.msec.2012.10.024

56. A. Azadbakht, A. Abbasi, Z. Derikvand, S. Amraei, Mater. Sci. Eng. C 2015, 48, 270-278.

DOI:10.1016/j.msec.2014.12.034

57. A. Salimi, H. Mamkhezri, S. Mohebbi, Electrochem. Commun. 2006, 8, 688-696. DOI:10.1016/j.elecom.2006.02.019 


\section{Povzetek}

Film rutenijev oksid heksacianoferat (RuOHCF) je bil elektrokemično deponiran na stekleno ogljikovo površino (GC) $\mathrm{z}$ uporabo zaporedne ciklične voltametrije kot posredne in zelene sintetične strategije. Elektrokemijsko obnašanje in elektrokatalizne lastnosti modificirane elektrode RuOHCF / GC so bile ovrednotene na podlagi elektroredukcije vodikovega peroksida in jodata $\mathrm{v}$ močnem kislems mediju $(\mathrm{pH} \mathrm{1,0-2,0)} \mathrm{z} \mathrm{uporabo} \mathrm{različnih} \mathrm{elektrokemijskih} \mathrm{tehnik,} \mathrm{vkl-}$ jučno s ciklično voltametrijo in amperometrijo s konstantnim potencialom. Elektrokemijske študije so pokazale, da ima RuOHCF / GC visoko katalitično aktivnost pri obeh študiranih reakcijah, hiter odziv in dobro obnovljivost signala za tok. RuOHCF / GC ima izboljšano elektrokatatalitsko vedenje v primerjavi z drugimi modificiranimi elektrodami iz literature. Enostaven in ponovljiv postopek za izdelavo elektrod, široko linearno območje, minimalne interference in dolgotrajna stabilnost RuOHCF / GC naredijo ta senzoričen material obetaven za praktično kvantitativno določanje vodikovega peroksida in jodata. Izjemno je, da je poročana modificirana elektroda zagotavljala nadčutljive občutljivosti $\left(1050 \mu \mathrm{A} \mathrm{mM}^{-1} \mathrm{~cm}^{-2}\right)$ in zelo selektivno amperometrično detekcijo jodata. 